\title{
A Course Based on Open Organization Principles
}

\author{
Heidi J. C. Ellis \\ Western New England University \\ Springfield, MA, USA \\ ellis@wne.edu
}

\author{
Gregory W. Hislop \\ Drexel University \\ Philadelphia, PA, USA \\ hislop@drexel.edu
}

\begin{abstract}
This poster presents a plan for a first-semester freshman computing course based on Open Organization principles using humanitarian organizations as the context. The goal of the course is to instill engagement with learning in students from the beginning of their academic careers when they are psychologically invested in their learning and more likely to internalize the learning. The anticipated outcome is students who are motivated, engaged, and able to handle the rapid rate of computing change in today's society.
\end{abstract}

\section{CCS CONCEPTS}

- Applied computing $\rightarrow$ Collaborative learning;

\section{KEYWORDS}

Open Organization, Humanitarian Computing, Computing education

ACM Reference format:

Heidi J. C. Ellis and Gregory W. Hislop. 2017. A Course Based on Open Organization Principles. In Proceedings of ITiCSE'17, fuly 3-5, 2017, Bologna, Italy., , 1 pages.

DOI: http://dx.doi.org/10.1145/3059009.3072998

\section{INTRODUCTION}

Computing is advancing at an exponential rate, resulting in a vast array of new technologies and ideas that are transforming the world dramatically. We must prepare motivated, engaged and empowered students who are able to contribute to the businesses that develop and support these new technologies and ideas.

An open organization is one that "engages participative communities both inside and out ... and inspires, motivates, and empowers people at all levels to act with accountability [2]." The open organization applied to education provides students and faculty with a high degree of choice and flexibility in an environment of trust, allowing students to learn at their own pace and according to their own styles. Students and faculty work together in community to transparently adopt new ideas and technologies.

\section{COMPUTATIONAL CULTURES}

Two sections of a first-semester freshman course titled "Computational Cultures" will be offered in fall 2017 at Western New England

Permission to make digital or hard copies of part or all of this work for personal or classroom use is granted without fee provided that copies are not made or distributed for profit or commercial advantage and that copies bear this notice and the full citation on the first page. Copyrights for third-party components of this work must be honored. For all other uses, contact the owner/author(s).

ITiCSE'17, fuly 3-5, 2017, Bologna, Italy.

(c) 2017 Copyright held by the owner/author(s). 978-1-4503-4704-4/17/07.

DOI: http://dx.doi.org/10.1145/3059009.3072998
University. Expected enrollment is 20 or fewer students per section with the majority of students being in the CS \& IT programs.

Course Description: This course explores the social, cultural, political, and economic forces surrounding the pervasiveness of computers and computational practices in everyday life, with emphasis on the rapidly expanding number of contexts in which familiarity of the computational is imperative today. Principles of Open Organization will be practiced in this course.

The course will utilize humanitarian projects as the domain for course deliverables. Students will collaborate to answer the question of how they can impact the world for the better through the project. Forms could take advocacy, marketing and community building, in addition to technical efforts. By setting their own purpose, it is hoped that students will create meaning and excitement in their work. Key principles of Open Organizations include:

Empowerment: Students decide about their learning directions including how to approach topics and course structure such as policies for attendance, late arrival, cell phone use, etc.

Manage by Example: The instructor will be transparent about the constraints on the course (timing, course goals, etc.) and work along with students to solve problems, modeling problem-solving behavior.

Fast Innovation: Assignments will involve a creative component where students can push the boundaries of their learning and take risks.

Incremental Improvement: An incremental approach will be taken in the course where students will learn that the first innovation will not be perfect and that an incremental process can be used to refine and ensure ongoing improvement to ideas.

Collaboration: All discussions will happen in public when possible, and all course decisions will be made in public.

In order to understand the impact of the course, engagement in the course will be assessed at the beginning and end using a known instrument such as [1].

\section{ACKNOWLEDGMENTS}

This material is based on work supported by the National Science Foundation under Grant Nos. DUE-1525039, DUE-1524877, and DUE-1524898. Any opinions, findings and conclusions or recommendations expressed in this material are those of the author(s) and do not necessarily reflect the views of the National Science Foundation (NSF).

\section{REFERENCES}

[1] James J. Appleton. 2006. Measuring cognitive and psychological engagement: Validation of the Student Engagement Instrument. Fournal of School Psychology 44, 5 (2006), 427-445.

[2] Jim Whitehurst. 2015. The Open Organization: Ignighting Passion and Performance. Harvard Business Review Press, Cambridge, Massachusetts. 